\title{
The Effects of Non-interest Banking on Entrepreneurship in Nigeria
}

\section{Larry Anifowose*}

Department of Entrepreneurship Management Technology, The Federal University of Technology, Akure, Ondo State, Nigeria

\begin{abstract}
For long, there has been controversy as to the banking system which involves no interest. The non- interest banking system has raised huge controversy and argument as to its relevance to the banking sector. It has also raised argument as to whether this type of banking system is relevant to entrepreneurs.

This paper tends to look at the relevance of non-interest banking on entrepreneurs. It would show to the reader that non- interest banking is very relevant to entrepreneurs. It would also show to the reader that non- interest banking helps entrepreneurs in raising capital and funds.
\end{abstract}

Keywords: Non-Interest banking; Entrepreneurship; Nigeria; Business opportunity; Economic resources

\section{Introduction}

Non-interest banking otherwise or also known as Islamic Banking is one which raised a lot of fumes in Nigeria and in the world over. Its usefulness as well as its religiosity raised a lot of controversy. Some have seen it as a good way of banking while others have given it a dismissal attitude.

If this is so, we would like to know what this system of banking entails and whether it is useful to the society and to entrepreneurs. In doing so, it raises a question in our mind. That is, "What is NonInterest Banking?"

Non-interest banking or Islamic banking is banking or banking activity that is consistent with the principles of sharia and its practical application through the development of Islamic economics. Also, according to Charles M. Hudwick, in his book Banking Evolution, 2008, pg. 205, Islamic banking refers to a banking activity or a system of banking that is in consonance with the basic principles of Islamic Shraiah (Rules and values set by Islam).

Furthermore, as defined by Abdul Gafoor in his book titled "Interest-free Commercial Banking", 1995, Islamic banking is a banking system which is based and propelled by the sharia. That is, all workings of Islamic banking must be in line with the sharia. Nothing is done by a non- interest bank without reference to the sharia and the Quran.

Having seen all the definitions above, I can stand on the authorities above and describe non- interest banking as a banking system which entails the banking in accordance and in cognisance with the sharia and the Quran.

\section{Definitions}

Entrepreneur: According to McConnell Brue, in his book titled microeconomics 1999, entrepreneurs are individuals who recognize or operate a business or businesses. He saw entrepreneurs as individuals who view and identify a business opportunity in the society and ensures that this opportunity is transformed to an enterprise.

According to Webster's dictionary and thesaurus, 2004 [1], entrepreneur is an individual who engages in the process of launching or managing a business venture. It viewed entrepreneurs as the individual who engage in the process of handling a business venture.

Also, Ricky Griffin in his book titled 'management' [2] described entrepreneurs as a person who directs the process of planning, organizing, operating and assuming the risk of a business venture. $\mathrm{He}$ further described entrepreneurs as all the events which are geared by individuals towards operating a business through risk taking.

Furthermore, Oxford dictionary, 5th edition defined entrepreneurs as the activities employed in the organization and risk taking in a business by an individual.

Also, in the year 1734, Richard Cantillon viewed entrepreneurs as non- fixed income earners who pay certain cost of production and earn uncertain incomes. He saw entrepreneurs as persons who pay a known amount of money for the production of a particular product and is likely to have an uncertain return from the goods.

In the year 1803, Jean- Baptiste Say defined an entrepreneur as an economic agent who unites all the means of production- land of one, the labour of another and the capital of yet another and thus produces a product. By selling the product in the market, he pays rent of land; wages to labour, interest on capital and what remains is his profit. $\mathrm{He}$ also saw entrepreneurs as one that shifts economic resources out of an area of lower and into an area of higher productivity and greater yield.

Furthermore, Horngren in his book titled Accounting defines an entrepreneur as an individual who employs all the needed resources (land, labour and capital) having identified an opportunity and taken the needed risks so as to attain and procure profit through the production of desired products which will satisfy the needs of consumers

Having seen all these, I can say that entrepreneurs are individuals, persons, group of persons or even a firm that employ all the needed resources and taking the risks involved so as to set up a business enterprise.

For the purpose of understanding this research work better, some

*Corresponding author: Larry Anifowose, Department of Entrepreneurship Management Technology, The Federal University of Technology, Akure, Ondo state, Nigeria, Tel: +2348025845959; E-mail: anifowosedotun@yahoo.com

Recieved August 21, 2014; Accepted October 17, 2015; Published October 26 2015

Citation: Anifowose L (2015) The Effects of Non-interest Banking on Entrepreneurship in Nigeria. J Entrepren Organiz Manag 4: 157. doi:10.4172/2169026X.1000157

Copyright: (c) 2015 Anifowose L. This is an open-access article distributed under the terms of the Creative Commons Attribution License, which permits unrestricted use, distribution, and reproduction in any medium, provided the original author and source are credited. 
terms which would be used are defined as follows:

Islam: A monotheistic faith regarded as revealed through Mohammed as the prophet of Allah. A religion characterized by the acceptance of the doctrine of submission to the will of Allah.

Sharia: The body of doctrines that regulates the life of those who profess Islam. The moral code and religious laws of Islam.

Quran: The sacred writings of Islam revealed by God to the prophet Mohammed during his life at Mecca and Medina. A sacred book divided into 1145 chapters, or suras: revered as the word of God, dictated by the prophet Mohammed.

Entrepreneur: A person who organizes and operates a business or businesses, taking on financial risk to do so. A person who, rather than working as an employee, runs a small business and assumes all the risk and reward of a given business venture, idea, goods or service offered for sale.

Interest: Mathematically, interest is the money paid for using someone else's money whether for personal or business use. It is normally calculated in percentage. It is referred to as "Riba" in Islamic terms.

Having analyzed all these words, we should have a clearer perspective as to this research.

\section{History of Islamic banking}

The origin of Islamic banking system can be traced back to the advent of Islam when the Prophet himself carried out trading operations for his wife. The "Mudarbah" or Islamic partnerships has been widely appreciated by the Muslim business community for centuries but the concept of "Riba" or interest has gained very little diligence in regular or day-to-day transactions.

The first model of Islamic banking system came into picture in 1963 in Egypt. Ahmad Al Najjar was the chief founder of this bank and the key features are profit sharing on the non interest based philosophy of the Islamic Shariah. These banks were actually more than financial institutions rather than commercial banks as they pay or charge interest on transactions. In 1974, the Organization of Islamic Countries (OIC) had established the first Islamic bank called the Islamic Development Bank or IDB. The basic business model of this bank was to provide financial assistance and support on profit sharing.

By the end of 1970, several Islamic banking systems have been established throughout the Muslim world, including the first private commercial bank in Dubai(1975), the Bahrain Islamic bank(1979) and the Faisal Islamic bank of Sudan (1977) [3,4].

\section{History of Islamic banking in Nigeria}

The history of Islamic banking in Nigeria is very short and not most individuals regard Islamic banking in Nigeria as having a history due to its young age. However, for the purpose of understanding this research, we would give a brief history about the history of Islamic banking in Nigeria.

Islamic banking was first introduced in Nigeria by the Central Bank of Nigeria (CBN) governor, Sanusi Lamido Sanusi as an alternative to the other forms of banking in Nigeria in the year 2010. He introduced this banking system so as to ensure that the excesses of the commercial banks where checkmated.

The first Islamic bank to be formed in Nigeria is the Jaiz Bank in the year 2003. Although it had been in existence before the official introduction of Islamic banking, it was until the formal introduction that this bank widened its operations.

Thus, we can say that the history of Islamic banking in Nigeria begins from 2010 and was propelled by the CBN governor [5].

\section{Literature Review}

Non-interest banking also known as Islamic banking can be portrayed as the youngest and most controversial banking system. This is because of its religious nature. Due to the fact that it is deeply rooted in Islam, it has had mixed reactions from several people.

However, this does not mean that this banking system is useless. In fact, it is very useful to individuals especially entrepreneurs. This is because it offers loans and assistance without collecting interest on these loans, thereby, facilitating entrepreneurship [6].

As we all know, the greatest problem of any and every entrepreneur is the problem of acquiring fund for the formation and management of the business. Thus, this banking system serves as a means of breaking this barrier and ensuring that entrepreneurs have adequate funding for their business.

If this is true, then, Islamic banking plays a vital role to every entrepreneur. Thus, it is useful. We would look in-depth as to the relevance of non- interest banking to entrepreneurs in the paragraphs below

\section{Relevance of non-interest banking to Entrepreneurs}

Islamic banking and the finance industry is growing at an annual rate of $20 \%$. Many international as well as local institutions have stepped into this multi-billion dollar booming industry by establishing its Islamic wings and units. International giant banks such as HSBC (HSBC Amanah), Citi Bank (Citi Islamic) and Standard Chartered have already established their Islamic units and functioning in the Middle East region.

In Sri Lanka, despite the Muslim population being just $8 \%$ of the total population, a considerable growth is reported in the past few years with the establishment of Amana, Ceylinco Profit Sharing, First Global and a new comer ABC Barakah. Recently it is reported that the largest state owned commercial bank, Bank of Ceylon intends to commence its Islamic banking unit in early 2008. All these new entries imply that this alternative banking system has drawn the attention of Muslims as well as non-Muslims due to its unique developmental characteristics.

The underlying principle of Islamic banks is the principle of justice which is an essential requirement for all kinds of Islamic financing. In profit sharing of a financed project, the financier and the beneficiary share the actual or net profit/loss rather than throwing the risk burden only to the entrepreneur. The principle of fairness and justice requires that the actual output of such a project should be fairly distributed among the two parties. If a financier is expecting a claim on profits of a project, he should also carry a proportional share of the loss of that project.

In contrast with conventional finance methods, Islamic financing is not centered only on credit worthiness and ability to repay the loans and interest by entrepreneurs; instead the worthiness and profitability of a project are the most important criteria of Islamic financing while the ability to repay the loan is sub-segmented under profitability.

One of the unique and salient characteristics of Islamic banks 
is that the integration of ethical and moral values with its banking operation. The ethical and moral consideration of Islamic banks cannot be detached and their behaviour should be consistent with the moral and ethical standards laid down by the Islamic Shari'ah. Thus, any entrepreneurial venture must be ethically sound.

Unlike the conventional banks, the financing of Islamic banks are restricted to useful goods and services and refrain from financing alcoholic beverages and tobacco or morally unacceptable services such as casinos and pornography, irrespective of whether or not such goods and services are legal or not in a given country, hence, ensuring that the entrepreneur does not become a criminal or engage in criminal activities.

In contrast with conventional banks, Islamic banks do not consider only the credit worthiness and interest rate as standards; instead they must apply Islamic moral/ethical criteria in their provision of financing. This adds another merit for Islamic banks since there is a beneficial impact on the productivity in the economy as it reduces the social and economic cost of such harmful products and activities [7].

Another important relevance which forms the basis for the development of Islamic banks is the relationship with depositors. They deal with their customers on investment grounds rather than a pre-determined fixed interest rate. They invest the money of their depositors on high profitable projects after going through a strategic analysis in order to give a substantial return to their depositors. In other words, the entrepreneur relates with the bank on the grounds of investment and not on the grounds of interest.

Thus in Islamic banking industry, each bank will attempt to out-perform other banks if it wants to attract funds from investors. And the ultimate result is that a high return on investments for the entrepreneur, which is unlikely in a conventional bank where it deals with entrepreneurs on a pre-determined fixed interest rate.

Furthermore Islamic banks eliminate the barrier between those who save and those who invest, and bring them closer to the real market. That is, it eliminates the barrier between individuals and entrepreneurs. The nature of the financial intermediation of Islamic banks significantly defers from conventional banks and it is in harmony with real market and developmental changes in it.

Having seen all these, let us look at the relevance of non- interest banking in a scholarly way with Nigeria as a case study.

\section{Importance of non-interest banking to entrepreneurs in Nigeria}

As already said, non-interest banking is very important to entrepreneurs. This is no different to the entrepreneurs in Nigeria. Non- interest banks serve very important use to the entrepreneurs in the following ways:

Capital formation: non- interest banking serves a major function of providing funds to the entrepreneurs. They do this by ensuring that anyone with a good business idea is supported and given fund to start and manage their businesses. This becomes one of the motivators that propel entrepreneurs to greater participation in the economy.

No interest loans: Non-interest banks otherwise known as Islamic banks give no interest loans to their customer. That is, their loans do not attract any interest. This is because the Holy Quran condemns the collection of interest. Thus, entrepreneurs enjoy the freedom of collecting loans without bothering about interest. This makes life a lot easier for entrepreneurs.

Equal opportunities: Non-interest banks give equal opportunities to all entrepreneurs. Unlike in the conventional banking system where loans are given according to credit worthiness and amount of money in one's account, Islamic banking grants loans on the profitability of one's idea. That is, one might not have so much money in his account but because he has a good idea, he can be able to secure a good loan from an Islamic banking.

Creation of better relationship amongst entrepreneurs: Noninterest banks creates better relationship between their customers. As the main aim of Islamic banking is to create a universal brotherhood amongst its customers and Muslims, it ensures that entrepreneurs have a good relationship existing between them. Thus, it enables them to be able to exchange ideas which would aid them in their innovation.

\section{Summary}

This research work centers on the relevance of Islamic Banking or otherwise called Non- interest banking on entrepreneurs. It studied briefly the history of Islamic banking system in chapter two, looking at it from the two aspects- the history of Islamic banking in the world and the history of Islamic banking in Nigeria.

It also studied the relevance of Islamic banking on entrepreneurs, explaining the reasons why this banking system is advantageous to entrepreneurs.

It finally came into conclusion about the relevance of Islamic banking on entrepreneurs drawing into attention about its usefulness in capital formation.

\section{Conclusion}

In conclusion, Islamic banking is very relevant to entrepreneurs. As the most difficult factor to every entrepreneur is the sourcing of capital, Islamic banking has now come into existence to break this barrier and ensure that entrepreneurs are no longer affected by capital.

\section{Recommendations}

In consideration of everything said above, we can recommend the following as recommendations so as to promote Islamic banking and its relevance to entrepreneurs.

Government should encourage entrepreneurs to undertake in Islamic banking as a source of securing loans and aids.

Government should make provisions and also invest in Islamic banking so that individuals and entrepreneurs may invest. Government should educate entrepreneurs and the entire public so that they may see this banking system as helpful to them and their business and not as a religious thing.

\section{Refernces}

1. Acs Z, Storey D (2004) Introduction: Entrepreneurship and Economic Development. Regional Studies 38: 871-877.

2. Griffin R (2005) Management. $8^{\text {th }}$ edn. Dreamtech Press, New Delhi, India.

3. Business Environment and Enterprise Performance Surveys (2007) Problems and Challenges of Small Medium Enterprises.

4. Ariyo D (2005) Small firms are the backbone of the Nigerian economy. Africa economic analysis.

5. Alao O (2005) Principles of Economics: Macro. Darkol Press and Publishers Isolo, Lagos. 
Citation: Anifowose L (2015) The Effects of Non-interest Banking on Entrepreneurship in Nigeria. J Entrepren Organiz Manag 4: 157. doi:10.4172/2169026X.1000157

Page 4 of 4

6. Brouwer MT (2002) Weber, Schumpeter and Knight on Entrepreneurship and Economic Development. Journal of Evolutionary Economics 12: 83-105.
7. Binks M, Vale P (1990) Entrepreneurship and Economic Change. London: McGraw Hill. 